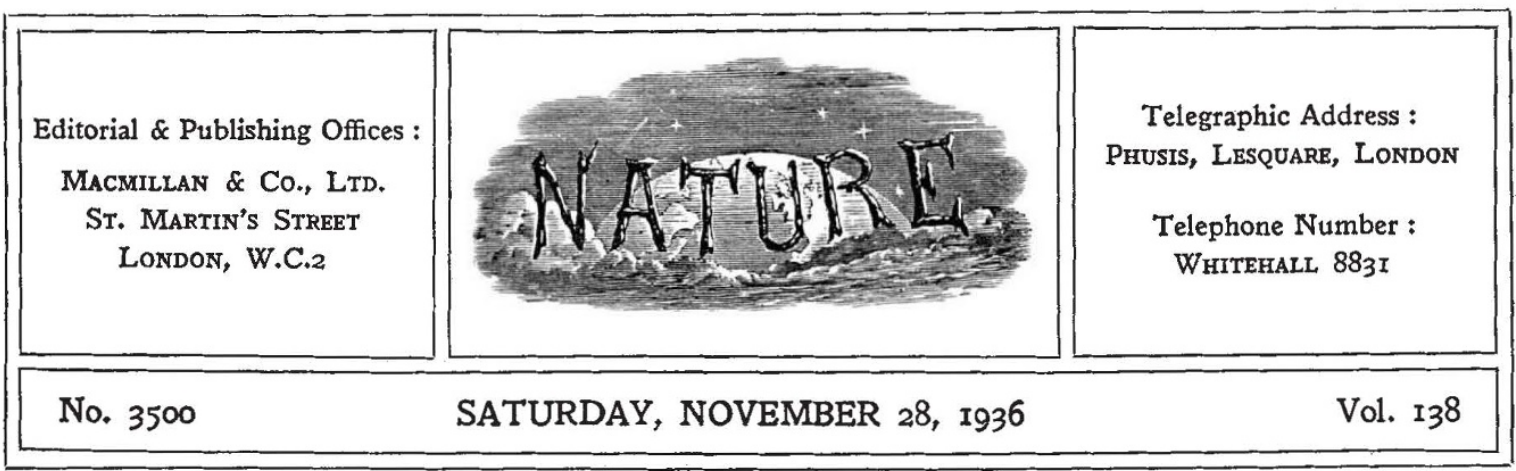

\title{
The Service of Unified Knowledge
}

$\int \mathrm{U}$ UST a century ago the library of that mighty book hunter, Richard Heber, came under the auctioneer's hammer, and two hundred and two working days were consumed in dispersing a hundred and twenty thousand volumes-a noble collection which yet did not represent more than a fragment of that portion of the world's thought heretofore collected between the covers of printed books.

What a change has come over the scene in the century that has passed! The staid astronomy over which Airy presided has expanded into a world picture wherein countless universes stream through space, and temperatures are reckoned in millions of degrees. The physical sciences are altered out of all recognition; their content has increased in an incredible ratio and, concurrently with an unprecedented increase in the technique of accurate measurement, has developed a doctrine of uncertainty which prescribes a limit to the accuracy of our knowledge. Theories of evolution have appeared on the scene, crossed the stage, and disappeared-possibly to reappear in modified form. Social systems, apparently stable, are in a state of flux; the father of sixty years since could train his son to a trade or profession with the reasonable expectation that the society in which he lived and moved would remain indefinitely stable; the father of to-day sees no such prospect. Youth is healthily critical of the fundamentals of our social system, and discourses copiously-sometimes perhaps a little superficially-concerning dialectical materialism and the Hegelian theory. And, if 'Whitaker' be a trustworthy guide-the year 1934 saw 15,436 new volumes thrown into this weltering confusion of assertion, argument and denunciation, in Great Britain alone.
What can be done about it? If there is one thing more certain than another, it is that some appreciation of the magnitude and mode of action of these forces of disintegration, of these rapidly changing aspects of political, moral and religious thought, of the social repercussions of the advances of scientific knowledge, must be the possession, not merely of an oligarchical or aristocratic governing class, but also of every man who by his vote or otherwise may influence the policy and outlook of the community of which he forms a unit.

Government to-day is much more of an art than a science, and grave questions of national policy are settled as the result of waves of mass-emotionemotion which may or may not have its origin in a wise, altruistic and rational attitude to the problems of life. It will always be so--great movements of humanity will ever be determined by the forces directed by the emotions and passions of mankind; and it is the business of all who can help, to do so by assisting each one of us to form, so far as his limitations of capacity and opportunity will permit, that background of ordered knowledge which so much enlarges his outlook and thereby his ability to think clearly and wisely, and to direct his emotions to a worthy end. Moreover, the need presses ; in more than one community where shallow draughts of psychology and philosophy have intoxicated the brain, we see a growing habit of depreciation of the actions of the intellect and of undue exaltation of emotional and intuitive processes.

We can at least provide the means towards supplying this need-we can, granted goodwill and energy, put at the disposal of every man, 
learned and unlearned, ordered statements of present-day knowledge in all branches of life and learning that the mind of man has traversed, and concerning which he has recorded his thoughts, his difficulties and conclusions in the pages of a book. Such a statement is an encyclopædia.

The notion of an encyclopædia is old enough, as old as the appreciation of the organic unity of knowledge- of the fact that the totality of knowledge is something more than the sum of its parts. The name is no older than 1541, the date of publication of Ringelberg's "Cyclopædia" at Basel ; the notion is possibly as old as Aristotle, whose mind was essentially encyclopædic-as Pliny's was not. But the great incentive to encyclopædia-building came from the labours of Francis Bacon, whose attempt at a systematic classification of knowledge fired the imagination of Diderot and inspired the labours of D'Alembert.

Our countryman, Ephraim Chambers, had the root of the matter in him when he remarked that, in his view of an encyclopædia, one should "consider the several matters not only in themselves, but relatively, or as they respect each other ; both to treat them as many wholes, and as so many parts of some greater whole". A truly admirable ideal; whether the "Cyclopædia or Universal Dictionary of the Arts and Sciences" (two volumes, folio; London, 1727) fulfilled these generous aspirations is another matter.

It cannot be too strongly emphasized that a true encyclopædia is something more than a bare summary of the knowledge of its day. Its articles may or may not be dashed off hastily - in the age of intellectual ferment that produced the great French Encyclopædia, articles were written at a white heat of enthusiasm, and it was just because that enthusiasm was linked with the forces of reason and of knowledge the French Encyclopædia became such a mighty weapon for the cause of progress. For that very reason it rallied, in the words of one of its great historians, "all that was then best in France round the standard of light and social hope".

So, too, the age that saw the passing of the Reform Bill saw the birth of a desire for the spread of positive knowledge that resulted in the publication of those remarkable volumes (twenty-seven of them, and two or three appendix-volumes) known as the "Penny Cyclopædia". He who has these volumes on his shelves will more willingly part with more pretentious cyclopædias. The wealth of articles contributed by Augustus de
Morgan will never lose their value; and the whole encyclopædia is a noteworthy record of the aspirations and limitations of a phase in our history marked by a special enthusiasm for "the particular go" of material things.

It was also, we note in parentheses, the England of the Oxford Movement. But it was also the England of the Society for the Diffusion of Useful Knowledge-a Society the activities of which produced an inimitable passage in "Crotchet Castle"-and the "Penny Cyclopædia" faithfully reflects that aspect of its age. Calculus and chronology are there in full measure ; the artistic and mystical side of life find but scanty record.

What type of encyclopædia will most fittingly serve the needs of our own age? Mr. Wells's vision sees a World Encyclopædia where all that is best of everything that need be said is gathered together in one great series of volumes-the best thoughts of the best writers-"selections, extracts, quotations, very carefully assembled with the approval of outstanding authorities in each subject, carefully collated and edited and critically presented".

It may well be so; this represents a high, though not an unattainable ideal. But though the difficulties are great and will have to be considered, we need not assume that the gain in authority of a collection and collation as nearly perfect as this imperfect world of ours will permit, will involve a loss of unity if control is entrusted to a band of learned workers informed with an enthusiasm for their task, and having a clear perception of the social needs of their age. It is, however, vitally necessary to realize such difficulties before embarking on the task of preparing an encyclopædia the influence of which may be so far-reaching.

Yet a further possibility should be considered. Entia non multiplicanda sunt praeter necessitatem, a dictum which is specially true of encyclopædias. But, broadly speaking, there is room and need for three types: the encyclopædia wherein the articles are written in terms of specialized knowledge ; the more popular encyclopædia written with an eye to the needs of the layman; and a really critical bibliography of existing knowledge which shall discriminate between the needs of the specialist and those of the layman.

Such a critical bibliography-an almost indispensable preliminary to the greater task-would place at man's disposal a weapon of immense social value. 